\title{
The Use of Syrian Sumac (Rhus coriaria) as a Meat Tenderizer: Effect on Fat, Protein and Collagen Profiles on Pectoralis superficialis Cut
}

\author{
Khaula Sakhr ${ }^{1, a}$, Sami El Khatib ${ }^{1, b, *}$ \\ ${ }^{1}$ Department of Food Science and Technology. School of Arts and Sciences, Lebanese International University. Al Khiara, West Bekaa, Lebanon \\ *Corresponding author

\begin{tabular}{l|l}
\hline A R T I C L E I N F O & A B S T R A C T \\
\hline Research Article & $\begin{array}{l}\text { The Syrian Sumac (Rhus coriaria) is a widely used spice in the Arab world of attractive economic } \\
\text { importance in food, cosmetic and pharmaceutical industries. Meat tenderness is one of the very most } \\
\text { important factors for customers' acceptability. The global objective of this study was to add an } \\
\text { additional value to Sumac by evaluating its meat tenderizing effect. Crude sumac fruits were used } \\
\text { to create three different extracts (aqueous, ethanolic and purified enzymatic extract). Pectoralis } \\
\text { superficialis cuts were treated with the extracts and studied for their shear stress, pH, protein and fat } \\
\text { contents and collagen. The hypothesis that Sumac could have a meat tenderizing effect was } \\
\text { supported by our results showing a significant decrease in shear stress and protein content with } \\
\text { increase in collagen solubility. Moreover, an effect on decreasing meat fat was detected, where the } \\
\text { aqueous sumac extract decreased significantly the fat percentage in meat. The active enzymes in } \\
\text { Sumac were shown to be variate in nature, lipase and protease, with a significant effect on collagen, } \\
\text { Accepted : 29/07/2019 } \\
\text { thus proving Sumac's possibility to be potentially used as a meat tenderizer. }\end{array}$ \\
$\begin{array}{l}\text { Keywords: } \\
\text { Syrian sumac } \\
\text { Three-phase partitioning } \\
\text { Meat tenderness }\end{array}$
\end{tabular}

Meat tenderness

Collagen

Fat content

\section{Introduction}

Meat tenderness is the most important characteristic for customer acceptability of meat. A cut of meat can be tender, tough or intermediate depending mainly on the type of the animal, the type of muscle (locomotive muscles are tougher than support muscles), its fat and connective tissue content and distribution (defined as marbling), as well as the degree of doneness after cooking. Some traits define a meat cut as tender or tough according to certain characteristics like sarcomere length, amount of stromal protein, collagen solubility, distribution of marbling, amount of fat and muscle fiber diameter (Morgan, 1991).

Pectoralis superficialis is the scientific name given to the meat cut commonly known as Brisket. Anatomically, it is positioned in the deltoid tuberosity and crest of the humerus with the brachiocephalicus. It is responsible for adducting the limb, protracting and retracting the limb as well as drawing the trunk sideways. According to the Institute of Agriculture and Natural resources of Nebraska, the processing characteristics of a boneless Brisket meat cut are of $10.6 \%$ fat content, $18.5 \%$ protein content, an intense connective tissue amount, shear stress of $4.86 \mathrm{~kg}$ and moderately tough texture (Bovine Myology). Because it supports $60 \%$ of the animal's weight, it is considered a tough, low-value meat cut (Zhu, 2017).

Proteases (also called peptidases or proteinases) are enzymes that hydrolyze the peptic linkages in protein into shorter fragments (peptides) and eventually into their components, amino acids. Since proteases represent more than $60 \%$ of the enzyme market share, they are the most important type of commercialized enzymes in the world (Lucas, 2017). The use of exogenous proteases, like bromelain, actinidin and papain, to improve meat tenderness has become an increasing focus of interest recently. It has been reported that only $10 \%$ of the carcass can be made into prime grilling tender cuts (Zhu, 2017), which means that the rest $(90 \%)$ can potentially benefit from meat tenderization methods, such as the use of exogenous enzymes. It is a priority for the meat industry to be able to cover the increasing demand for guaranteed tender meat and give added value to lower-grade meat cuts. 
Many approaches have been based on improving postmortem tenderness, such as mechanical tenderization, water content enhancement, and different enzymatic treatments (Lucas, 2017).

Actinidin is extracted from kiwifruit. Like Bromelain, Ficin and Papain, it is a proteolytic enzyme potentially used as a meat tenderizer. Except for kiwifruit concentrate, Actinidin has not been approved to be Generally Recognized as Safe (GRAS) by the FDA. The application of Actinidin in the industry is promising because of its less intensive tenderization on meat and broader specificity compared with other traditional enzymes. It has shown the ability to hydrolyze myofibrillar proteins and connective tissues (Bekhit, 2007; Christensen, 2009; Han, 2009; Lewis, 1988 and Wada, 2002).

Sumac is a commonly used spice in the Arab world. Although used as a powder, its natural state is a fruit. From the species Anacardiaceae and genus Rhus, Sumac is the generic name used to indicate the spice product of the plant Rhus coriaria. The name "Sumac" comes from "summāq" which means "dark red" in Arabic (Abu Reidah, 2014). Rhus coriaria has an attractive economic importance due to its increasing use in food, cosmetic and pharmaceutical industries, coloring or preservation of foods and veterinary practices (Turk, 2010). However, its use is generally restricted to food condiment, with little use otherwise, despite its big potential.

Sumac could be considered as one of the artisanal condiments used in Lebanese rural regions. The enzymatic characterization of Sumac has never been elaborated, neither has its effect as a meat tenderizer. The main objectives of this study were to evaluate the tenderizing potential of different sumac fruit extracts: sumac aqueous extract (SAE), sumac isolated enzyme (SIE), sumac ethanolic extract (SEE), on Brisket meat, scientifically named Pectoralis superficialis. In addition, its crude protein content, crude fat content and amount of stromal protein were evaluated before and after treatment. Kiwifruit extract was used as a positive control and nontreated samples were considered as negative control. The results showed a potential of sumac being used as a meat tenderizer due to its effect on muscle protein and collagen. As a plus, a lipolytic effect has been found when treating the meat with sumac aqueous extract, opening up a broad spectrum of studies to be done further on Sumac in order to promote its more extensive use in the food industry.

\section{Factors that Affect Meat Tenderness}

Meat quality is highly determined by customers' satisfaction. Although it's based on multi-dimensional attributes, some characteristics like color, smell and fat content directly influence the consumers' choice. Also, the tenderness and flavor of the cut after cooking are the main factors that determine palatability and influence the purchase (Zhu, 2017). Composition, texture, slaughtering and storage are factors that affect the tenderness of the cut.

The bovine muscle is composed of muscle fibers covered by layers of connective tissue (Listrat, 2016). Collagen content and distribution along with fat content are the main factors affecting meat tenderness. Not only that, the degree of use of that muscle also determines toughness. The higher the strength applied on the muscle and the older the animal, the tougher the meat cut is. Therefore, all meat tenderization methods should target collagen content to attain a tenderer cut (Dinh, 2006).

In addition to that, post-mortem conditions affect the tenderness of the meat exponentially. The meat toughens at the beginning due to the automatic muscle contraction and, although the animal is dead, its muscles continue their metabolism anaerobically through a process known as rigor mortis. In a living animal, ATP levels in the muscles prevent the fibers from sticking to each other. After slaughtering, the anaerobic process begins to hydrolyze the glycogen stored in the muscles into lactic acid, decreasing the meat $\mathrm{pH}$. Once the $\mathrm{pH}$ is lowered, this process will stop due to the deactivation of the glycolytic enzymes and the ATP levels will drop, thus sticking the muscle fibers and toughening the meat. Cathepsin, calpain and collagenase enzymes only function at low $\mathrm{pH}$, which is when it is activated and begin to hydrolyze muscle proteins, causing it to tenderize (Dinh, 2006).

\section{Methods Used for Meat Tenderization}

In order to increase meat tenderness, several methods have been used all over the years. Mechanical pounding and mincing, ageing, ultrasound and microwave processing, as well as freezing/thawing meat cuts are all physical methods used to increase meat tenderization. Not only that, but also chemical methods are applied for the same purpose such as using calcium to activate calpains (enzymes activated after rigor mortis), or marinating with maltodextrin and starch solutions (Zhu, 2017). Recently, attention has been turned into exogenous proteases for its use in meat. These are extracted from plants, such as papain, bromelain, ficin, zingibain and actinidin, from microbes or animals (Whitehurst, 2010). Enzymes have shown to be more specific in terms of target proteins (Bekhit, 2014). For example, Zingibain has a higher specificity towards collagen than actinidin, and a Bacillus subtilis (Arshad, 2016) protease has a higher specificity for myofibrilar proteins than for collagen (Zhu, 2017). The degree of myofibrillar proteins and collagen hydrolysis of exogenous proteases is evaluated based on its shear force and sensory measures of tenderness, protein content, solubilized collagen and percent collagen solubility (Seggren, 2000).

\section{Tenderness Classification of Beef}

The most common objective method used to quantify the degree of meat tenderness is called Warner-Bratzler shear force analysis. This device records the amount of force required to shear a core of meat. The National Cattlemen's Beef Association studied and classified every meat cut according to its degree of tenderness and determined the shear force needed to deform a Pectoralis superficialis cut to be $47.6 \mathrm{~N}(4.86 \mathrm{~kg})$, its fat content to be $106.6 \mathrm{mg} / \mathrm{g}$ of fresh meat $(10.6 \%)$ and its protein content to be $187.5 \mathrm{mg} / \mathrm{g}$ of fresh meat (18.7\%) (Seggren, 2000).

Mostly, tender cuts come from the middle of the animal, for example the rib and loin. This is because these are support muscles that receive less exercise and contain less connective tissue. Tougher cuts are from the front and rear parts of the animal, like the brisket and round, because these are constantly moving muscles that develop more connective tissue (Morgan, 1991).

The tenderness of meat is divided into four categories. Based on the criteria for meat texture set by Bellew et al, 
meat cuts with shear force values less than $31.38 \mathrm{~N}(3.2 \mathrm{~kg})$ are considered very tender, shear force values from 31.4 to $38.25 \mathrm{~N}(3.2-3.9 \mathrm{~kg})$ are considered tender, from 38.3 to $45.1 \mathrm{~N}(3.9-4.6 \mathrm{~kg})$ are considered intermediate and shear force values greater than $45.1 \mathrm{~N}(4.6 \mathrm{~kg})$ are considered tough cuts (Shackelford, 1999).

Effect of Heat on Muscle Fibers and Collagen in Meat According to Morgan et al. from the National Cattlemen's Beef Association, the method of cooking has no significant effect on the beef proteins. According to the authors, the different effects on meat proteins is determined by heat (Morgan, 1991).

A study by Kemp et al. measured the heat needed to denature individual protein components (Myofibril and Stromal proteins) over a range of 20 to $90^{\circ} \mathrm{C}$ and found that myofibrillar proteins denature at temperatures between 55 and $60^{\circ} \mathrm{C}$, whereas the stromal proteins denature at about $60^{\circ} \mathrm{C}$. The shrinkage of collagen fibers is initiated at 60 to $70^{\circ} \mathrm{C}$. At higher temperature $\left(>75^{\circ} \mathrm{C}\right)$, gelatinization of the collagen occurs (Yu, 2016).

Beef with higher levels of connective tissue, such as Brisket cuts, need longer, slower cooking (moist cooking) to allow time for the connective tissue to convert to gelatin and become tender. Dry heat methods, which are characterized by quick cooking at higher temperatures, use uncovered pans, direct heat and no additional liquid (Morgan, 1991).

On that scope, a study by Wall et al. evaluated the effect of heat on the sensorial characteristics of meat and found that grill surface temperature had no effect on trained panel tenderness scores and concluded that the tenderness and juiciness of steaks grilled at different temperatures were not perceived to be different by consumers (Wall, 2018).

\section{Rhus coriaria (Syrian Sumac) Background}

Rhus coriaria has an attractive economic importance due to its increasing use in food, cosmetic and pharmaceutical industries, coloring or preservation of foods and veterinary practices (Turk, 2010).

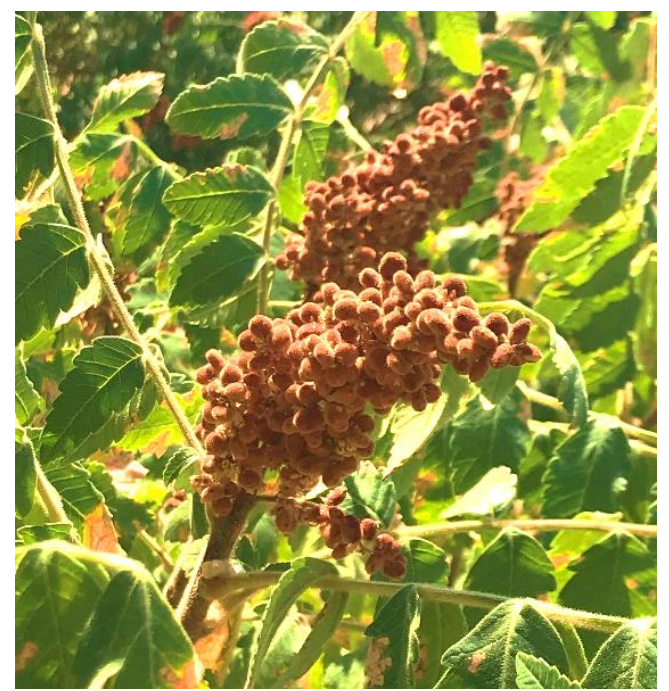

Figure 1: Sumac fruits agglomerated in clusters. Photo taken in a Sumac Field in Baaloul, West Bekaa Lebanon (September, 2018)

Chemical Composition of Rhus coriaria: Hydrolysable tannins compose the highest percentage in the Sumac fruits, followed by flavonoids (Ardalani, 2016). This emphasizes the antioxidant potential of the fruit. Subsequently there are anthocyanins, isoflavonoids, terpenoids and diterpenes (Ardalani, 2016). A study on the chemical properties of sumac fruit was conducted on ripe fruits and have found a $2.6 \%$ protein content, $7.4 \%$ fat content, $14.6 \%$ fiber content, $1.8 \%$ ash. Also, a calorimetric calculation showed that $100 \mathrm{~g}$ of sumac fruit contains $147.8 \mathrm{kcal}$ (Ozcan, 2004).

Therapeutic Effects of Rhus coriaria: Sumac's potential therapeutic effect has been evaluated by several studies which identified its antibacterial power (Aljaber, 2008), antifungal (Erturk, 2010), antioxidant (AlMuwaly, 2013) and anaelgesic effects (Mohammadi, 2016). Also, its antilipidemic (Boroujeni, 2016) and hypoglycemic effects (Shidfar, 2013; Anwer, 2013) has been proved effective.

Rhus coriaria uses in the Food Industry: In addition, researchers have been analyzing its potential as preservatives (Abdelmalek, 2013; Obais, 2013), antioxidant (Bursal, 2010; Almouwaly, 2013) and colorant (Dabas, 2016) for its use in the food industry.

It has also been shown to have a potential for inhibiting steel in sea water (Anaee, 2016) and in dentistry, where it efficiently suppressed Streptococcus mutans, the main bacteria causative of dental caries and plaque (Dastjerdi, 2014).

\section{Materials and Methods}

The fruits of Lebanese Rhus coriaria were used to create three extracts. One simple aqueous extract (SAE), a sumac isolated enzyme extract (SIE) and a sumac ethanolic extract (SEE). The produced extracts were tested on Pectoralis superficialis meat cuts in order to evaluate its tenderizing effect and its effect on the meat's protein, fat and collagen content.

\section{Sample Preparation}

The Sumac fruits were harvested in their cluster form from a single private orchard in Baaloul West Bekaa, Lebanon in August 2017. The clusters were sun dried for three days following the traditional methodology of sumac preparation. After being semi-dried, the clusters were separated from the stems using a traditional tool commonly known as "Masrad". These were sundried furthermore and sieved once again.

The sumac fruits were macerated into powder at a local mill at Kamed El Louz, West Bekaa, Lebanon.

\section{Extracts Preparation}

The aqueous extract was prepared as described by Gagaoua et al. (2014) with some modifications, by blending $125 \mathrm{~g}$ of sumac fruit powder with $300 \mathrm{ml}$ of distilled water for 2 minutes. The mixture was then strained using a cheesecloth. $50 \%$ and $100 \%$ concentrations were prepared to be used immediately.

The sumac ethanolic extract was prepared as described by Nagappan (2012), with some modifications. $50 \mathrm{~g}$ of sumac fruit powder were added to $500 \mathrm{ml}$ of $95 \%$ pure ethanol and stirred for 10 hours. The mixture was then filtered and evaporated using a RotaVap (R-100 Buchi Switzerland) machine. The Extract can be stored at $-30^{\circ} \mathrm{C}$ until use. 
The extraction of the enzyme was conducted using a Three Phase Partitioning TPP method as described by $\mathrm{C}$. Rachana et al. (2014) with some modifications (Figure 2). $100 \mathrm{~g}$ of sumac powder were mixed with $10 \mathrm{mmol}$ of $\mathrm{L}$ cysteine and covered with $50 \mathrm{mM}$ of Sodium Phosphate buffer at $7.0 \mathrm{pH}$. The mixture was continuously stirred for 45 minutes at $4^{\circ} \mathrm{C}$ and then filtrated using 3 layers of cheesecloth. The filtrate was centrifuged at 4000rpm for 15 minutes at $4^{\circ} \mathrm{C}$. Once collected, the supernatant was mixed with ammonium sulfate to produce a solution of $80 \%$ saturation. The same amount of 50mM Sodium Phosphate buffer was added and the mixture was left overnight at $4^{\circ} \mathrm{C}$. After that, $50 \%(\mathrm{w} / \mathrm{v})$ ammonium sulfate were added as well as 1:1 t-butanol. The mixture was vortexed gently and incubated for 1 hour at room temperature. The solution was then added to $50 \mathrm{ml}$ conical tubes and centrifuged at 4500 $\mathrm{rpm}$ for 10 minutes at $4^{\circ} \mathrm{C}$. Three phases were formed (upper organic, lower aqueous and interfacial precipitate). The interphasial precipitate (Figure 2) and aqueous phase were separately collected to be used as marinades. Also, a mixture 1:1 of SIE and TPP-AP was produced to be used as a marinade as well.

The kiwi fruit extract was used as a positive control for its content of Actinidin, a protease previously shown to have meat tenderizing effects (Sugiyama, 2005). The fruit was obtained from a local fruit market and the extract prepared was, based on the procedure of Sugiyama et al. (2005) $50 \mathrm{~g}$ of the peeled kiwi fruit were blended and strained to obtain a juice. It was directly used after preparation in order to minimize the autolysis of kiwi fruit proteases.

\section{Meat Sample Preparation}

The meat was bought from a local reputable butcher seller in Baaloul, West Bekaa, Lebanon and prepared accordingly to each analysis.

The meat cuts used in the shear stress test was prepared, as described by Font-i-Furnois et al. (2015) with some modifications, by cutting the meat into $3 \mathrm{~cm}$ thick steak and dividing it into $3 \times 3 \mathrm{~cm}$ squares. The meat was directly marinated and stored at $4{ }^{\circ} \mathrm{C}$ for 48 hours.

The meat samples used in the tests of $\mathrm{pH}$, crude protein and crude fat were pulverized finely and weighed. $5 \mathrm{~g}$ of meat were placed into small ziplock bags and $5 \mathrm{ml}$ of each extract was poured into the bag with meat (1:1 extract:meat). The bags were tightly sealed and left to marinate for 48 hours at $4^{\circ} \mathrm{C}$.

The meat samples used in the test for amount of stromal protein was prepared as described by Mitchell et al. (1926) The meat was freed from all visible fat and surrounding connective tissue and pulverized using a medium cutting plate. $250 \mathrm{~g}$ of meat were macerated with $300 \mathrm{ml}$ of distilled water using a small ball mill for 90 minutes. $20 \mathrm{~g}$ of the macerated meat were then collected and stored in small sealable bags (Figure 3 ). $20 \mathrm{ml}$ of each extract were poured inside each bag and left to marinate for 48 hours at $4^{\circ} \mathrm{C}$.

For the shear stress, $\mathrm{pH}$ and crude protein tests, the meat was cooked using a dry method of cooking, specifically pan frying, at high heat. The cooking of the meat was done using an electric kitchen plate of brand Mondial, which allows an even distribution of heat across all the surface and meat pieces. The temperature used in all samples was $120^{\circ} \mathrm{C}$. The meat cut was cooked for max two minutes on each side as recommended by Morgan et al. (1991) who specified that dry methods are characterized by quick cooking at high temperatures (Morgan, 1991). The meat samples were removed from heat after cooking and used in the subsequent measurements.
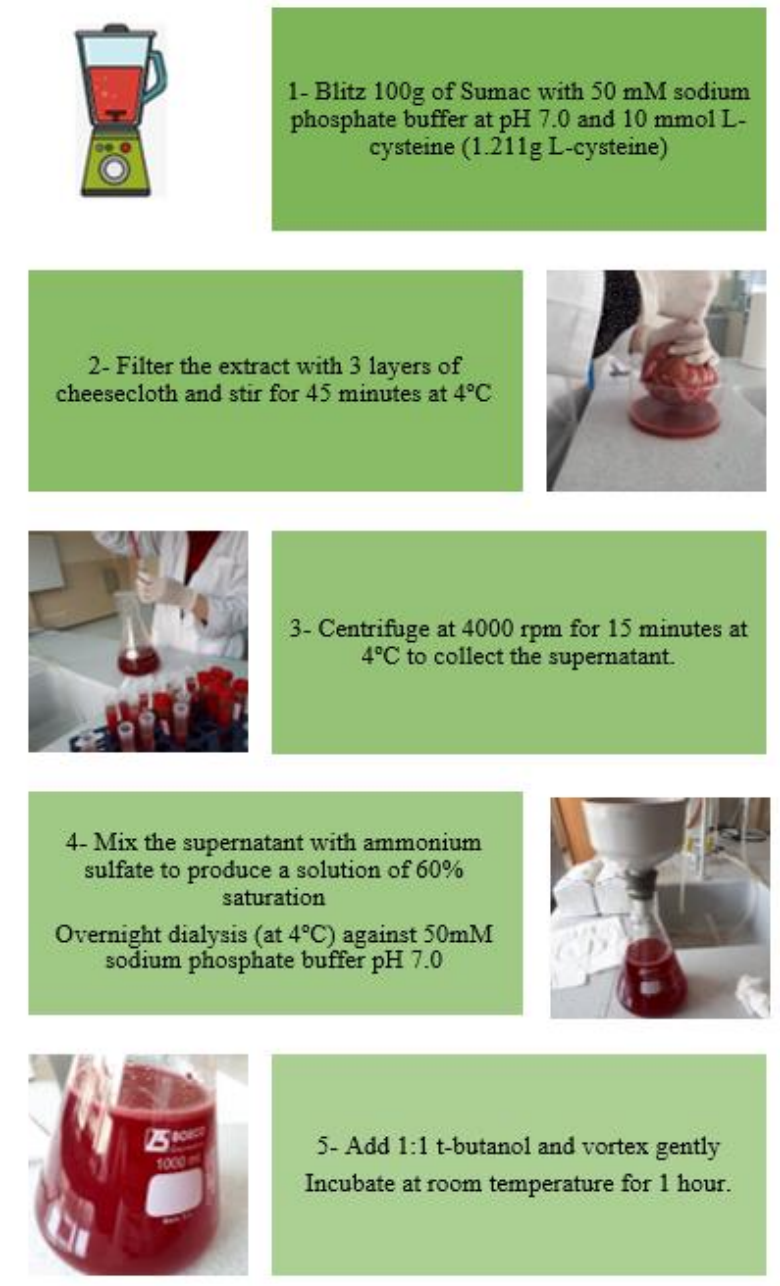

5- Add 1:1 t-butanol and vortex gently Incubate at room temperature for 1 hour.
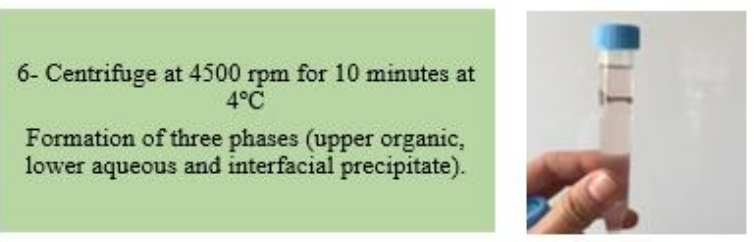

Figure 2 Process flow diagram of Three-Phase Partitioning (TPP) enzyme extraction (Rashana, 2014)

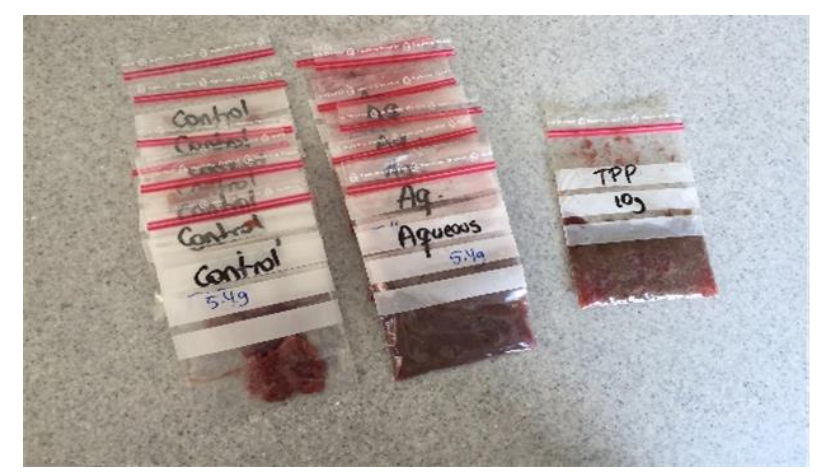

Figure 3 Meat samples ready to marinate ( $\mathrm{pH}$ test samples) 

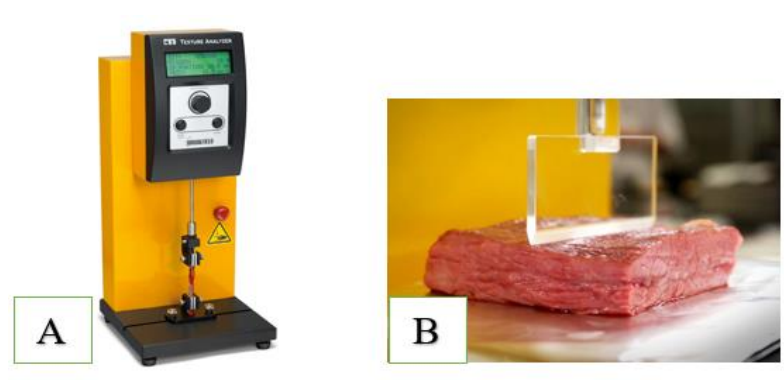

Figure 4 Brookfield CT3 Texture Analyzer. (A) shows the apparatus and (B) shows how it's applied on meat

Table $1 \mathrm{pH}$ values of Marinate, Raw Treated and Cooked Treated Meat

\begin{tabular}{|c|c|c|}
\hline Marinate & Raw Marinated Meat & Cooked Meat \\
\hline \multicolumn{3}{|c|}{ Sumac Fruit Aqueous Extract 50\% } \\
\hline 2.943 & 4.45 & 5.13 \\
\hline \multicolumn{3}{|c|}{ Sumac Fruit Aqueous Extract $100 \%$} \\
\hline 2.89 & 3.9 & 4.43 \\
\hline \multicolumn{3}{|c|}{ Sumac Fruit Ethanolic Extract } \\
\hline 5.62 & 5.86 & 5.89 \\
\hline \multicolumn{3}{|c|}{ TPP Aqueous Phase } \\
\hline 3.19 & 4.23 & 4.506 \\
\hline \multicolumn{3}{|c|}{ Sumac Fruit Isolated Enzyme Extract } \\
\hline 4.03 & 4.87 & 5.07 \\
\hline \multicolumn{3}{|c|}{ Kiwi Extract 50\% } \\
\hline 3.63 & 5.22 & 5.55 \\
\hline \multicolumn{3}{|c|}{ Kiwi Extract $100 \%$} \\
\hline 3.563 & 4.86 & 5.49 \\
\hline \multicolumn{3}{|c|}{ Negative Control } \\
\hline NA & 5.69 & 5.92 \\
\hline
\end{tabular}

NA: Not applicable

Table 2 Shear Stress Values

\begin{tabular}{c|c}
\hline Raw Meat Final load (N) & Cooked meat Final load (N) \\
\hline Sumac Fruit Aqueous Extract 50\% \\
\hline 63.56 & 43.72 \\
\hline Sumac Fruit Aqueous Extract $100 \%$ \\
\hline 42.9 & 20.76 \\
\hline Sumac Fruit Ethanolic Extract 100\% \\
\hline 77.2 & 153.25 \\
\hline \multicolumn{2}{|c}{ TPP Aqueous Phase } \\
\hline 78.31 & 139.09 \\
\hline Sumac Fruit Isolated Enzyme Extract \\
\hline 12.31 & 28.92 \\
\hline \multicolumn{2}{|c}{ TPP mix } \\
\hline 158.51 & 91.42 \\
\hline Positive Control (Kiwi Extract) 50\% \\
\hline 14.33 & 45.83 \\
\hline Positive Control (Kiwi Extract) $100 \%$ \\
\hline 9.04 & 60.18 \\
\hline Negative control (No treatment) \\
\hline 102.97 & 72.93 \\
\hline
\end{tabular}

\section{Physiochemical Evaluation}

The following physiochemical properties were evaluated:

The $\mathrm{pH}$ of all marinated and all cooked samples was measured using a $\mathrm{pH}$ meter as described by the SOP of the instrument (Hanna Instruments). $10 \mathrm{~g}$ of each sample were blended with $100 \mathrm{ml}$ distilled water for 30 seconds. $\mathrm{pH}$ was measured and recorded (Table 1).
The shear stress of each meat cut was calculated using a Texture Analyzer of brand Brookfield, Ametec, model CT3, available at Poppins Co. of Daher Groups.

The meat was evaluated both raw and cooked with three replicates each, following the instrument's manual for the application on meat. The meat cuts (raw and cooked) were placed in the texture analyzer fixture base table, with compression blade perpendicular to the longitudinal orientation of the muscle fibers arbitrarily. Shearing was conducted and each piece is sheared once in the center (Figure 4b). Values were recorded for each piece tested (Table 2).

The amount of stromal protein in meat is the amount of connective tissue present in the cut. Mitchell et al. (1926) have developed a method for the determination of the characteristic proteins of connective tissue in meat. The procedure was conducted by transferring the marinated sample onto a 40 mesh sieve, rejecting the filtrate (Figure 5). The residue was washed thoroughly using approximately $300 \mathrm{ml}$ of cold distilled water and transferred into a mortar for further maceration. After that, the sample was transferred to a beaker, stirred thoroughly and filtered again onto a 40 mesh sieve. This process was repeated 7-8 times to remove all the water- soluble protein and most of the finely divided granular material. The residue was then transferred to an $800 \mathrm{ml}$ beaker, covered with $400 \mathrm{ml}$ distilled water and heated for 2 hours in an autoclave (JP Selecta, model 230 VAC, Spain) under 1 bar pressure. After that, the hot supernatant was decanted through a fluted filter paper collecting the filtrate into a $1 \mathrm{~L}$ volumetric flask. The residue on the filter paper was again washed into a $500 \mathrm{ml}$ beaker with $100 \mathrm{ml}$ hot water and boiled for a few minutes. This process was repeated five times. Finally, the filtrates were diluted to the $1 \mathrm{~L}$ mark of the volumetric flask. The whole solution was filtrated one last time and aliquots were taken to evaluate the collagen using a spectrophotometer at 218, 240 and 540nm. The values were recorded (Table 5) and evaluated statistically.

There is no specific single wavelength for the quantitation of collagen by spectrophotometry. Although some studies were undergone to standardize this process, a single wavelength has not been set and studies are lacking in this matter. We based our measurements on the results of Jeevithan et al. who found that the maximum absorbance of collagen was obtained at 240nm (Jeevithan, 2015) and on the results of Jin et al who measured collagen absorbance at 218nm wavelength (Jin, 2011).

The method used for crude protein determination was the Kjeldahl digestion followed by a titrimetric determination of nitrogen and protein. The meat samples were marinated for 48 hours in Sumac Fruit Aqueous Extract SAE, Sumac Fruit Ethanolic Extract SEE, Sumac Fruit Isolated Enzyme Extract SIE, Kiwi Fruit Extract KFE, and Negative control (No treatment).

The process was done as stated by the FAO Manual for Food Quality Control. 1g of sample was weighed and placed into a $250 \mathrm{ml} \mathrm{Kjeldahl} \mathrm{test} \mathrm{tube.} \mathrm{For} \mathrm{each} \mathrm{sample,}$ $0.25 \mathrm{~g}$ Copper Sulfate, $20 \mathrm{ml}$ concentrated (98\%) sulphuric acid, and $5 \mathrm{ml}$ hydrogen peroxide $(30 \%)$ were added. A blank was made with all the components except for the sample. The samples were digested using a FoodAlyt Kjeldahl Digestion Unit (SBS800 model) at $350^{\circ} \mathrm{C}$ for 30 minutes and at $420^{\circ} \mathrm{C}$ for 160 minutes, until the fumes 
faded almost completely and the liquid turned into a clear greenish solution. After cooling, the liquid is water-clear and ready for distillation, which was done using a FoodAlyt D4000 Distillation Unit. The distillation begins by adding $30 \mathrm{ml}$ of $4 \%$ Boric Acid with methyl orange indicator to the receiving flask. Then, $50 \mathrm{ml}$ of distilled water and $70 \mathrm{ml}$ of $\mathrm{NaOH}$ were added to the digested flask until the medium was basic. Steam distillation begins automatically for 5 minutes. At the end of distillation, approximately $200 \mathrm{ml}$ of distilled solution is produced. This is divided into 3 flasks of $20 \mathrm{ml}$ for titration with $0.1 \mathrm{M} \mathrm{HCl}$.

Table 3 Crude Protein content Values of \% Nitrogen and $\%$ Protein

\begin{tabular}{cc|cc}
\hline \multicolumn{2}{c}{ Raw Meat Samples } & \multicolumn{2}{c}{ Cooked Meat Samples } \\
\hline $\mathrm{N}$ & $\mathrm{PS}$ & $\mathrm{N}$ & $\mathrm{PS}$ \\
\hline \multicolumn{3}{c}{ Sumac Fruit Aqueous Extract } \\
\hline 3.07 & 19.18 & 3.58 & 22.4 \\
\hline \multicolumn{3}{c}{ Sumac Fruit Isolated Enzyme Extract } \\
\hline 3.38 & 21.1 & 3.81 & 23.79 \\
\hline \multicolumn{3}{c}{ Ethanolic Extract } \\
\hline 6.03 & 6.45 \\
\hline \multicolumn{3}{c}{ Positive Control (Kiwi Fruit Extract 100\%) } \\
\hline 3.54 & 22.1 & 3.86 \\
\hline \multicolumn{3}{c}{ Negative control - No Treatment } \\
\hline 5.54 & 34.59 & 5.27 \\
\hline
\end{tabular}

$\mathrm{N}$ : Nitrogen, PS: Protein in sample

Table4 Crude Fat Content

\begin{tabular}{c|c}
\hline Crude Fat\% & $\mathrm{mg} / \mathrm{g}$ fresh weight \\
\hline \multicolumn{2}{|c}{ Sumac Fruit Aqueous Extract } \\
\hline 10.06 & 163.26 \\
\hline Sumac Fruit Isolated Enzyme Extract \\
\hline 15.12 & 262.68 \\
\hline Positive control (Kiwi Extract) \\
\hline 16.83 & 304.40 \\
\hline Negative control (No treatment) \\
\hline 15.86 & 289.87 \\
\hline
\end{tabular}

Table 5 The mean amount of stromal protein

Spectrophotometric Absorbance Wavelength

\begin{tabular}{l|cc}
\hline Initial Weight (g) & $\mathrm{OD}_{240}$ & $\mathrm{OD}_{218}$ \\
\hline Sumac Fruit Aqueous Extract & 1.28 & 2.24 \\
Sumac Fruit Isolated Enzyme Extract & 0.49 & 1.65 \\
Positive Control (Kiwi Extract) & 0.6 & 1.78 \\
Negative Control (No treatment) & 0.16 & 0.53 \\
\hline
\end{tabular}

The calculation of Nitrogen percentage was done using the following equation:

$$
\% \mathrm{~N}=\frac{(\text { TAVS-TAVB }) \times \mathrm{AC} \times 1.4007}{\mathrm{SW}} \times 100
$$

Where;

TAVS : Titrating acid volume for sample (ml)

TAVB : Titrating acid volume for blank

AC : Acid concentration

SW : Sample weight $(\mathrm{g})$
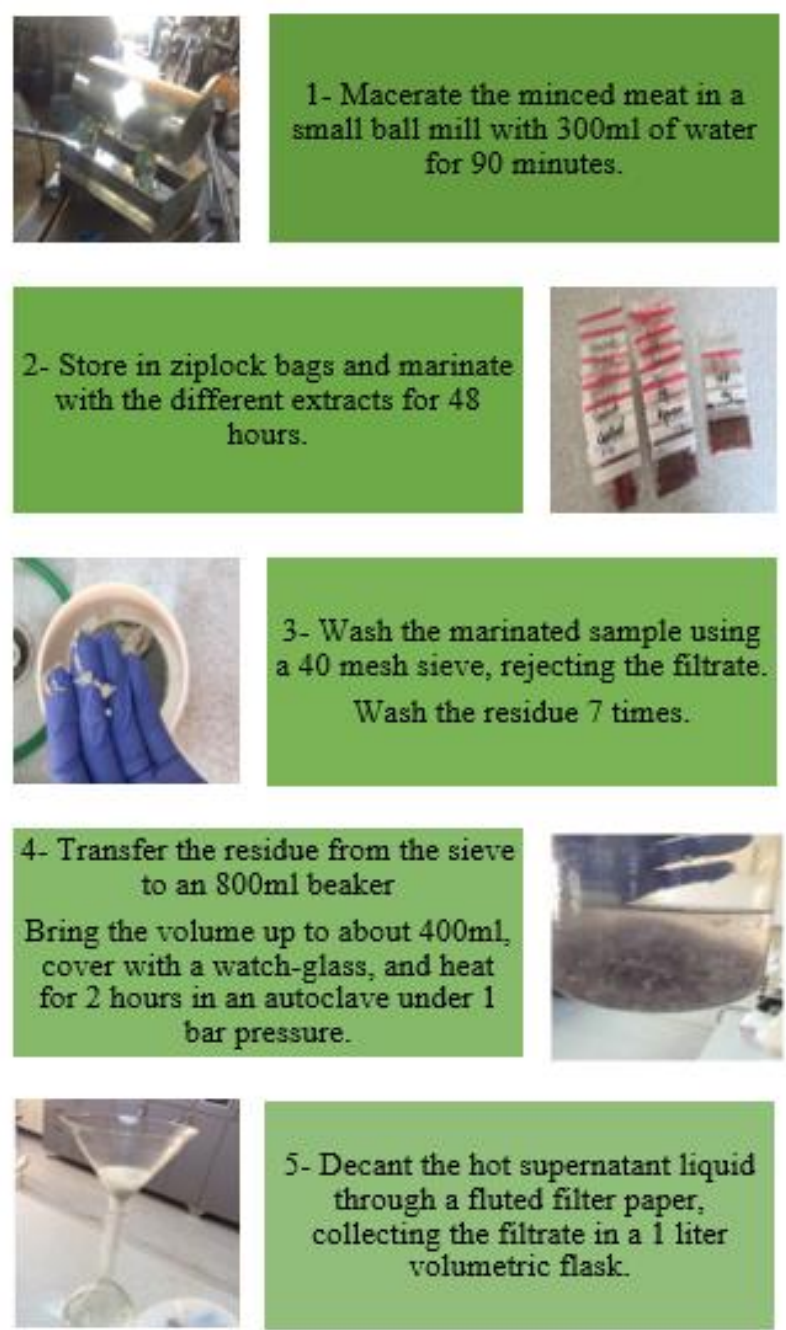

5-Decant the hot supernatant liquid through a fluted filter paper, collecting the filtrate in a 1 liter volumetric flask.

\section{6- Wash the residue on the filter back into the beaker with $100 \mathrm{ml}$ of hot water, boil for a few minutes, and filter again. This process was repeated five times.}
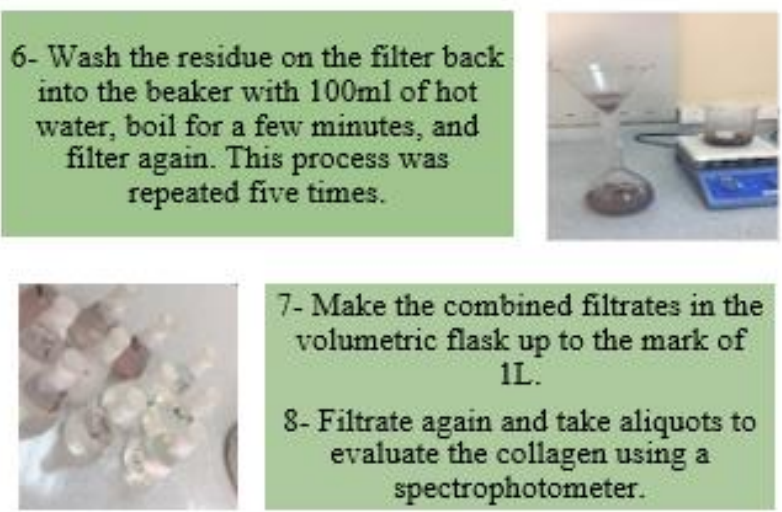

Figure 5 Process flow diagram of the extraction of collagen for analysis of amount of stromal protein

To calculate the \%Protein, the \%Nitrogen was multiplied by 6.25 protein factor as recommended by the FAO Manuals of Food Quality Control.

The values were recorded (Table 3 ) and evaluated statistically.

The meat samples were extracted using AOAC International Official Method 960.39 (Fat or Ether Extract in Meat). The Soxhlet apparatus used was of brand FoodAlyt, model RS 40. The meat samples were marinated for 48 hours at $4{ }^{\circ} \mathrm{C}$ in SAE, SIE, KFE and Negative control. The process was done as described in the FAO Manuals of Food Quality Control with some modifications. 
The thimbles were labeled and weighed. $5 \mathrm{~g}$ of each sample were weighed into the thimble and dried in the oven for 1.5 hours at $125^{\circ} \mathrm{C}$. The thimble + sample were weighed after drying and placed into the Soxhlet extraction machine. The extraction was done using $150 \mathrm{ml}$ of petroleum ether for 4 hours at a condensation rate of 5-6 drops per second at $65^{\circ} \mathrm{C}$. After extraction, the thimbles were dried completely and weighed. The fat content was calculated by subtracting the weight of the thimble after extraction from its weight after drying and the fat percentage and the $\mathrm{mg}$ of fat/g of fresh weight were calculated. The values were recorded (Table 4) and evaluated statistically

\section{Statistical Analysis}

The statistical analysis was performed using SPSS 22.0 software. The significance of the results was evaluated using Analysis of Variance (ANOVA) and Post Hoc tests Tukey and Dunnett were performed to compare the treatments' means and significance.

Statistical analysis was first made to compare means of the treated samples and control, to evaluate whether there is any evidence that the means of the samples differ. After finding evidence that the group means differ, we investigated which of the means are different. To do so, we used Tukey's multiple comparison test. The test compares the difference between each pair of means. The results are presented as a matrix showing the result for each pair as a $\mathrm{p}$ value $(\mathrm{P}<0.05$ shows a significant difference and $\mathrm{P}>0.05$ means there is no significant difference).

\section{Results and Discussion}

Despite its numerous potential effects, Sumac uses in the food industry is still infrequent. The main objective of this study was to try to shed the light into the capabilities of Sumac, which go far beyond its use as a simple food condiment and explore it differently. Being mainly an artisanal condiment used mostly in rural regions and in traditional foods, Sumac has much more potential to be investigated. The hypothesis that Sumac could have a meat tenderizing effect was supported by our results. Moreover, an effect on decreasing fat content and increasing collagen solubility was detected. Our study consisted of different tests made to englobe several factors that might affect the meat after treatment. These tests are $\mathrm{pH}$, shear stress, crude protein content, amount of stromal protein (collagen) and crude fat content.

\section{Physiochemical Analysis}

pH analysis: We compared the $\mathrm{pH}$ of each marinade solutions and found that the $\mathrm{SAE}$, of $\mathrm{pH} 2.89$, is four times more acidic than that of KFE, which $\mathrm{pH}$ is 3.56. This result is similar to that of Raodah et al. which found that the $\mathrm{pH}$ of sumac fruit is 3.02 (Raodah, 2014). Normal raw meat $\mathrm{pH}$ ranges from 5.4 to 5.79 (Lomiwes, 2012). Several studies have shown that a significant relationship exists between meat $\mathrm{pH}$ and meat tenderness after cooking. These studies have characterized the relationship between $\mathrm{pH}$ and tenderness during ageing such that meat toughness peaks between $\mathrm{pH} 5.4$ to 6.0 , and then subsequently decreases as $\mathrm{pH}$ increases beyond $\mathrm{pH} 6.0$ (Lomiwes, 2012).

SEE did not change the $\mathrm{pH}$ of the raw and cooked meat cuts after treatment when compared to that of the negative control. After treatment, SEE showed a pH of 5.86 in the raw treated meat cut, similar to that of the negative control which showed a $\mathrm{pH}$ of 5.69 and showed consistent to the cut offs for normal meat $\mathrm{pH}$ (Lomiwes, 2012). When comparing the treated meat cuts to the negative control, SIE and KFE treated meats, of $\mathrm{pH}$ values of 4.87 and 5.86 respectively, were 6.3 times more acidic than the untreated meat cuts. SAE decreased the $\mathrm{pH}$ in the raw meat almost eight times more than KFE.

After cooking, all meat cuts showed an increase in $\mathrm{pH}$. This is due to the myoglobin denaturation after cooking (King, 2006). The negative control showed the highest $\mathrm{pH}$ of 5.91, followed by SEE, of pH 5.89 and KFE, of pH 5.48. $\mathrm{KFE}$, although acidic, did not change the $\mathrm{pH}$ in meat after cooking as much as SAE, which $\mathrm{pH}$ decreased to 4.43 being twenty five times more acidic than the negative control. After cooking, KFE was only 2.5 times more acidic than the negative control. On the other hand, SIE showed a pH of 5.07 after cooking and is thus comparable to KFE in terms of final acidity.

Shear stress: In order to determine if there is a mechanical tenderizing effect, shear stress of the meat cut was measured. Slice shear stress measures the force needed, in $\mathrm{kg}$, to cause a deformation in the meat sample. This measurement is done to mimic the force needed to chew the piece of meat while eating. The higher the shear stress, the tougher the meat and vice versa.

The meat cuts were cooked using a dry cooking method, which is usually used for tender meat cuts. This was done evaluate whether the tenderness of the meat after treatment could be comparable to that of tender cuts.

A decrease in shear stress was detected in Sumac Aqueous Extract (SAE), which registered 42.86N (4.37kg) in the shear stress test, compared to the negative untreated control of shear stress $102.97 \mathrm{~N}(10.5 \mathrm{~kg})$ (Figure 6). In order to emphasize its effectiveness, a difference was shown between the two different concentrations of SAE and KFE. SAE100 showed 30\% less shear stress force than SAE50 and so did KFE100 with 52\% less shear stress than KFE50. So, the more concentrated the extract is, the higher its efficiency. A substantial decrease in shear stress was seen in the Sumac Isolated Enzyme Extract (SIE) treated meat, with a shear stress of $11.77 \mathrm{~N}(1.2 \mathrm{~kg})$. These results were comparable to that of KFE, with $0.92 \mathrm{~kg}$ shear stress, which has been proved to have a proteolytic and thus tenderizing effect on meat (Sugiyama, 2005). Compared to the negative control, SAE100 showed a decrease of 59\% in shear stress, thus effectively tenderizing the meat cut. Moreover, SIE showed a substantial decrease of $88 \%$. SEE and TPP-AP raw meat cuts showed a slight decrease of $23 \%$ in shear stress. However, this decrease was counteracted after cooking, where the shear stress increased disparately to $101 \%$ higher than the negative control, thus revealing really tough meat cuts.

In order to evaluate the efficacy of the enzyme, we used a mix of SIE and TPP-AP (TPP-mix), with the intent to evaluate whether there was any residual enzymatic activity in the aqueous phase of the extracted enzyme. The results obtained from the TPP-mix, summed up to the results of the TPP-AP, confirmed that all enzymatic activity was concentrated in the SIE and no residual activity was found in the aqueous phase of the TPP extraction. 
After cooking, a decrease of $71 \%$ in shear stress was shown in the SAE treated meat compared to that of the negative control. This result was higher than that of KFE, which showed a decrease of $36 \%$ only. Also, SIE registered a shear stress $60 \%$ lower than that of the negative control, which proved its tenderizing capacity and protease activity.

Because collagen gelatinization occurs only above $100^{\circ} \mathrm{C}$ and needs longer periods of cooking ( $\left.\mathrm{Yu}, 2016\right)$, the probability of the tenderness measured to be caused by collagen gelatinization is very low. This way, we can determine if the tenderization occurred as an effect of the treatment and not due to the heat during cooking.

On the other hand, SEE, TPP-AP and TPP-mix registered shear stress values higher than that of the negative control. This implies that the marinade solutions not only did not have a tenderizing effect, but also prevented the endogenous enzymes, responsible for the rigor mortis phenomenon described earlier, to occur. This finding was further confirmed in the crude protein content analysis.
Crude protein content: So far, these results suggest that the extracted enzyme is in fact a protease in nature. A decrease in protein content in the SAE, SIE and KFE treated meats was seen in both raw and cooked samples, suggesting that there was an actual protease activity. A decrease of $41.7 \%$ protein content was seen in the SAE treated meat samples. Similarly, SIE decreased protein content by $39 \%$. SAE and SIE showed a higher proteolytic activity than that of KFE, which caused a decrease of $35 \%$ of protein content compared to the negative control (Figure 7).

The negative control used in our study showed a protein content of $37.2 \%$. Compared to the same cut analyzed by the Institute of Bovine Myology, which contains $187.5 \mathrm{mg}$ of protein per $g$ of fresh meat (18.5\%) (Morgan, 1991), our samples contain almost double the amount of protein. This could be explained by several factors that affect the muscle constitution like breed, animal feed, animal age and muscle work (Yu, 2016; Morgan, 1991), which may differ substantially from a region to another. Furthermore, in order to determine if there was an effect on the connective tissue of the meat, collagen was studied.

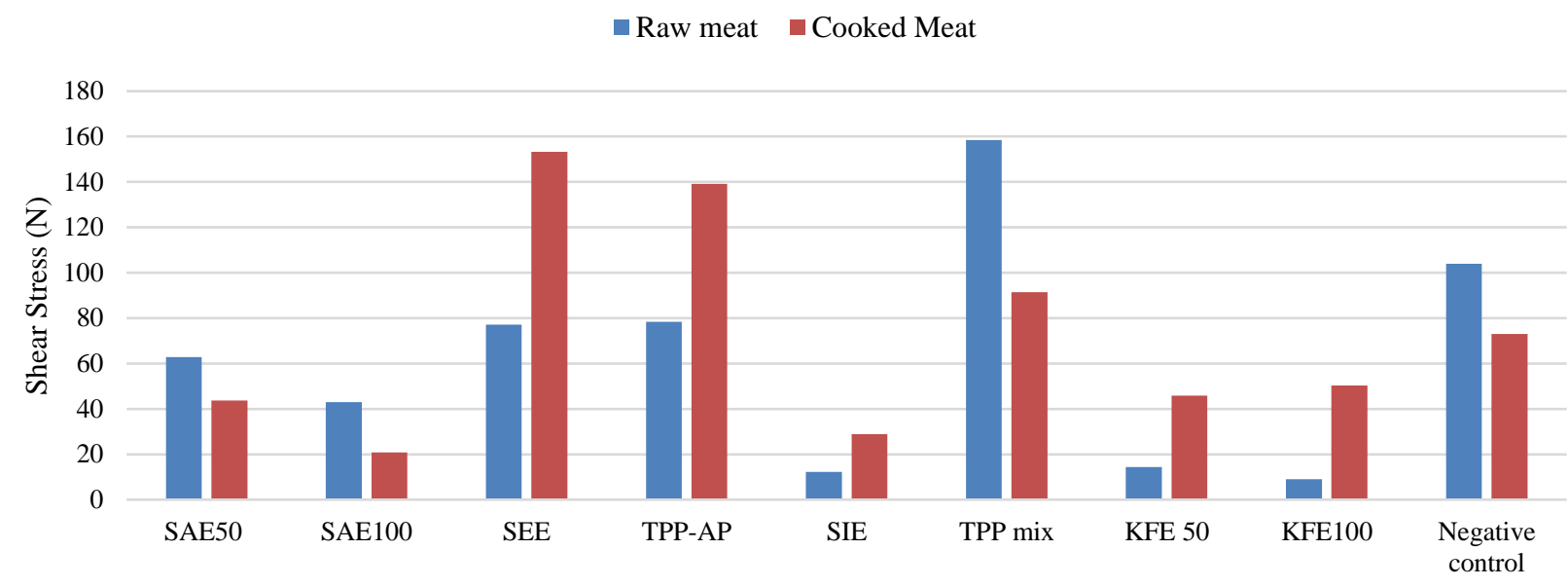

Figure 6 Graph showing the shear stress values of raw and cooked meat samples obtained after treatment of the meat with different extracts and without treatment

(SAE 50: Sumac Aqueous Extract 50\% concentration; SAE 100: Sumac Aqueous Extract 100\%; SEE: Sumac Ethanolic Extract; TPP-AP: ThreePhase Partitioning Aqueous Phase Extract; SIE: Sumac Isolated Enzyme Extract; KFE 50\%: Kiwi Fruit Extract 50\% concentration; KFE 100: Kiwi Fruit Extract 100\% concentration; Negative control: no treatment)

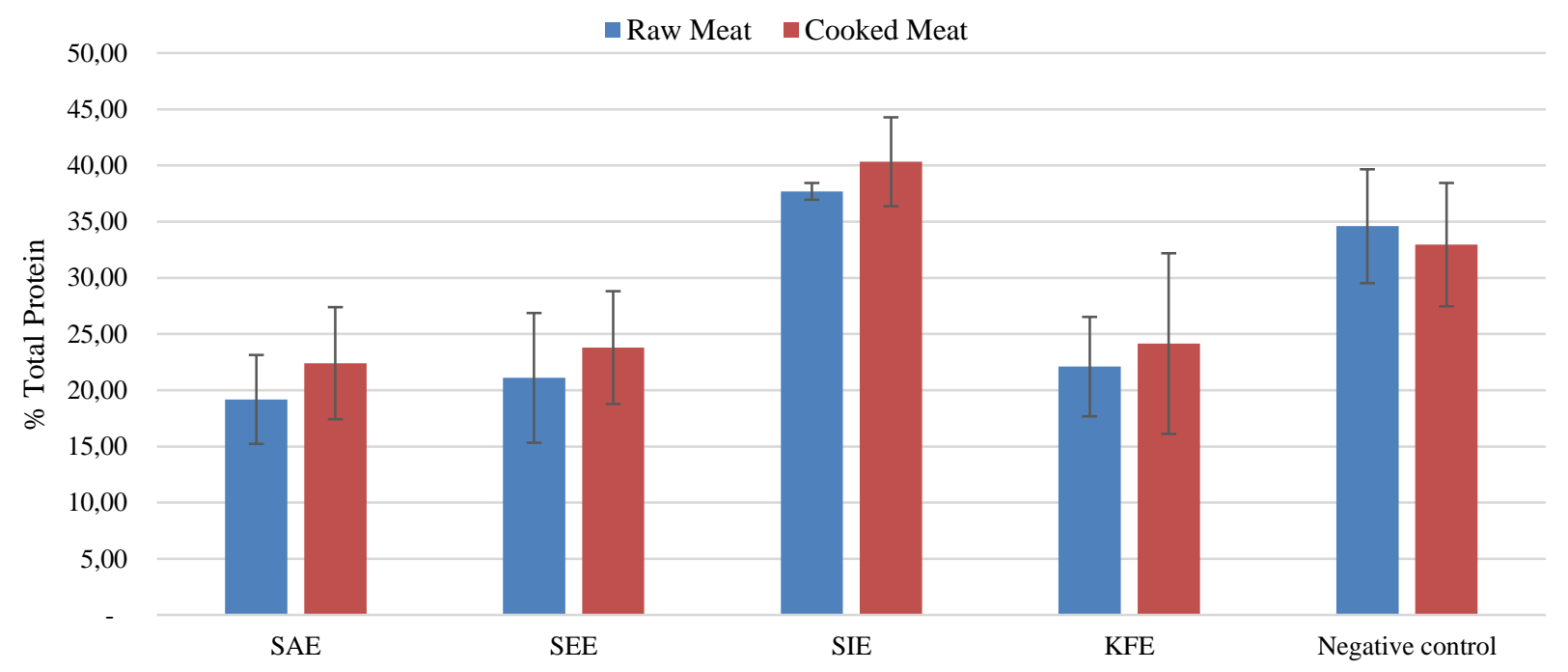

Figure 7 Graph showing the Total Protein percentage of the negative control and the treated samples 
In accordance to the crude protein content found in the raw meat samples, the results were similar after cooking. The highest protein content decrease was attained by the SAE, which hydrolyzed $32 \%$ of the proteins in the sample. Similarly, SIE and KFE had a protein content decrease of $30.5 \%$ and $29.6 \%$ respectively. As a final confirmation for the inefficiency of the SEE, it showed an increase in protein content compared to that of the negative control, once again emphasizing the inactivity of the rigor mortis in the SEE treated meat samples.

After these results, the continuation of the experiments was given with the exclusion of the SEE treatment due to its ineffectiveness as a meat tenderizer.

Amount of stromal protein: The amount of stromal protein, collagen, was analyzed by extracting the collagen first with a high heat process and then analyzing it spectrophotometrically. Collagen is mainly composed of the amino acids glycine, proline, alanine, hydroxyproline and glutamic acid. So to choose the best wavelength in order to measure the amount of collagen in the prepared liquid, we referred to previous studies that followed similar procedures using spectroscopy (Arunmozhivarman, 2017; Schmid, 2001; Jin, 2011). A study by Schmid from the University of Bayrouth in Germany assured that the concentration of proteins in a solution can be accurately determined by absorbance methods. According to the authors, the absorbance is related to the intensity of light before and after its passage through the protein solution and thus, the absorbance depends linearly on the concentration of proteins in the solution (Schmid, 2001). Another study conducted in China on the characterization of soluble bone collagen measured collagen concentrations spectrophotometrically on a UV range of 190-400nm (Jin, 2011). More specifically, Arunmozhivarman et al determined the maximum spectroscopic collagen absorption to be at 240nm (Arunmozhivarman, 2017). Regardfully, we measured the absorption of the collagen solutions at three different wavelengths and the highest absorption was obtained at wavelength $218 \mathrm{~nm}$. Our results showed that the absorption of collagen was highest in the SAE treated meat (1.28), followed by KFE (0.6) and SIE (0.5) and was the lowest in the negative control samples (0.16). This suggests that SAE had the highest effect in solubilizing the collagen.

The results also suggest that the extracted enzyme might possibly be a collagenase in nature. In order to confirm that, a study on the collagen solubility of meat treated with SAE and SIE should be done. This was also confirmed by the visual appearance of the collagen strings isolated during washing. The collagen treated with SAE was clearly more gelatinous in appearance than the negative control (Figure 8), suggesting that it had an effect in hydrolyzing the collagen.

The KFE treated meat had a lower effect on collagen than SAE and similar to that of SIE. The enzyme retrieved from Sumac using TPP has L-cysteine as a co-factor. This suggests that probably some other enzyme (maybe a collagenase) was still present in the SAE and could not be retrieved by the same TPP procedure due to a possible different co-factor needed. Therefore, in order to extract the collagenase present in the SAE, a different amino acid co-factor, specific to collagenase enzymes, should be used in the TPP process instead of or in conjunction with the L- cysteine. The effect of kiwi on meat is mainly on the globular protein, not as a collagenase (Sugiyama, 2005). However, it had a higher effect on collagen than that of SIE, suggesting again that the collagenase enzymes are concentrated in the SAE. Further studies should be conducted in order to determine the presence of other enzymes in the SAE.

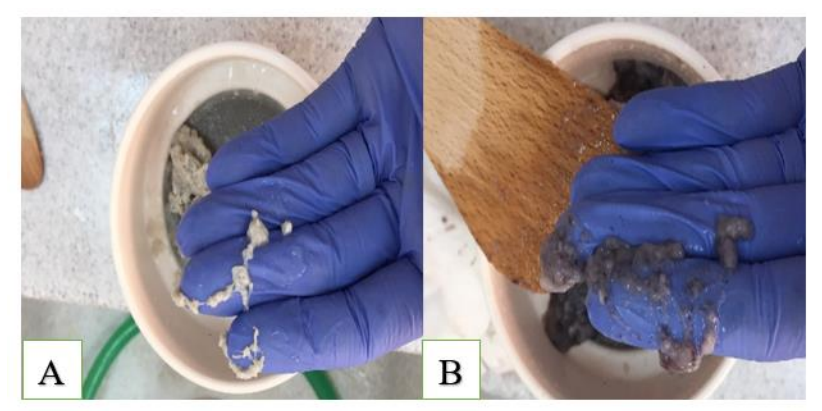

Figure 8 Meat collagen after washings. (A) shows the negative control connective tissue and (B) shows the connective tissue of the meat treated with sumac fruit

Crude fat content: The Bovine Myology Institute identifies a Pectoralis superficialis cut to contain $10.6 \%$ fat (Bovine Myology, 2017). Our result for the negative control was of $15.85 \%$ fat content. This result was in concordance with the SIE and KFE treatments, which showed a $15.2 \%$ and $16.8 \%$ fat content respectively and no effect on fat content whatsoever (Figure 9).

The results of fat analysis of the samples showed that only the meat treated with SAE had a significant decrease in fat content compared to the negative control. SAE decreased the fat content of the meat by $37 \%$. SIE and KFE treated meats had no lipolytic effect whatsoever. This suggests that the SAE not only contains proteases that may aid in meat tenderization but also contains lipases capable of hydrolyzing the fat in meat. The inactivity of SIE on fat also confirmed that the enzymes isolated are purely proteases and that no lipases were extracted in the TPP process. Further studies could be done to evaluate Sumac as a fat burner in healthy animals, thus possibly being used as a natural tool to decrease blood cholesterol levels and aid in weight loss.

\section{Correlational Analysis}

Correlational analyses were done to evaluate whether or not certain results like shear stress or fat percentage were affected by other factors other than the treatment applied.

Crude fat content versus $\mathrm{pH}$ : This was done to evaluate if the $\mathrm{pH}$ of the treatments had any effect on fat content (Figure 9).

Although the low $\mathrm{pH}$ of the sumac fruit extracts was proportional to the lowered fat percentage in the SAE and SIE, KFE had no effect on fat percentage despite its low $\mathrm{pH}$. This implies that the low $\mathrm{pH}$ did not affect the fat content in meat in KFE and, therefore, may have been coincidental in the SAE. However, it is possible that the enzymes present in sumac, which differ from that in kiwi, are influenced and act better in an acidic environment. This feature should be further studied to identify the optimal conditions in which the Sumac fruit enzymes works. 


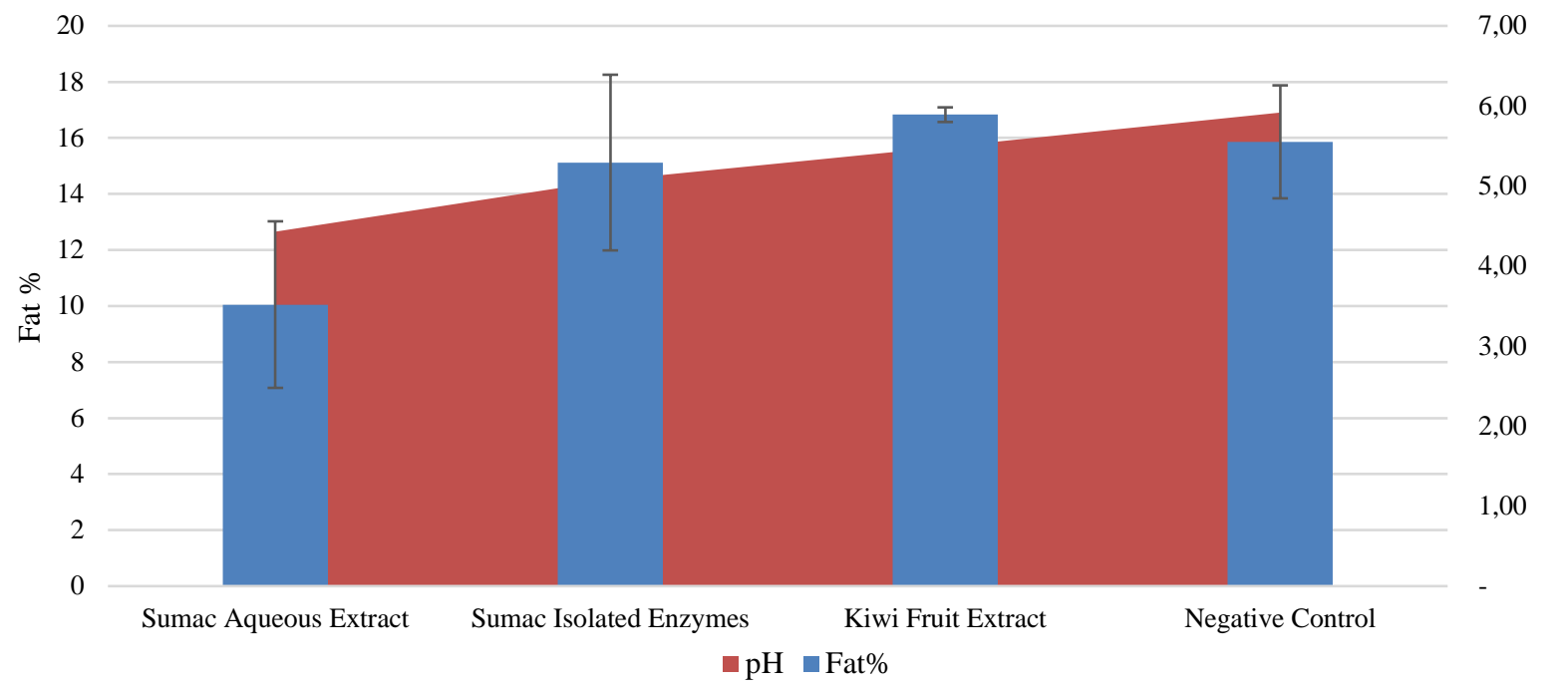

Figure 9 Graph showing the correlation between $\mathrm{pH}$ and the final fat $\%$ of the meat

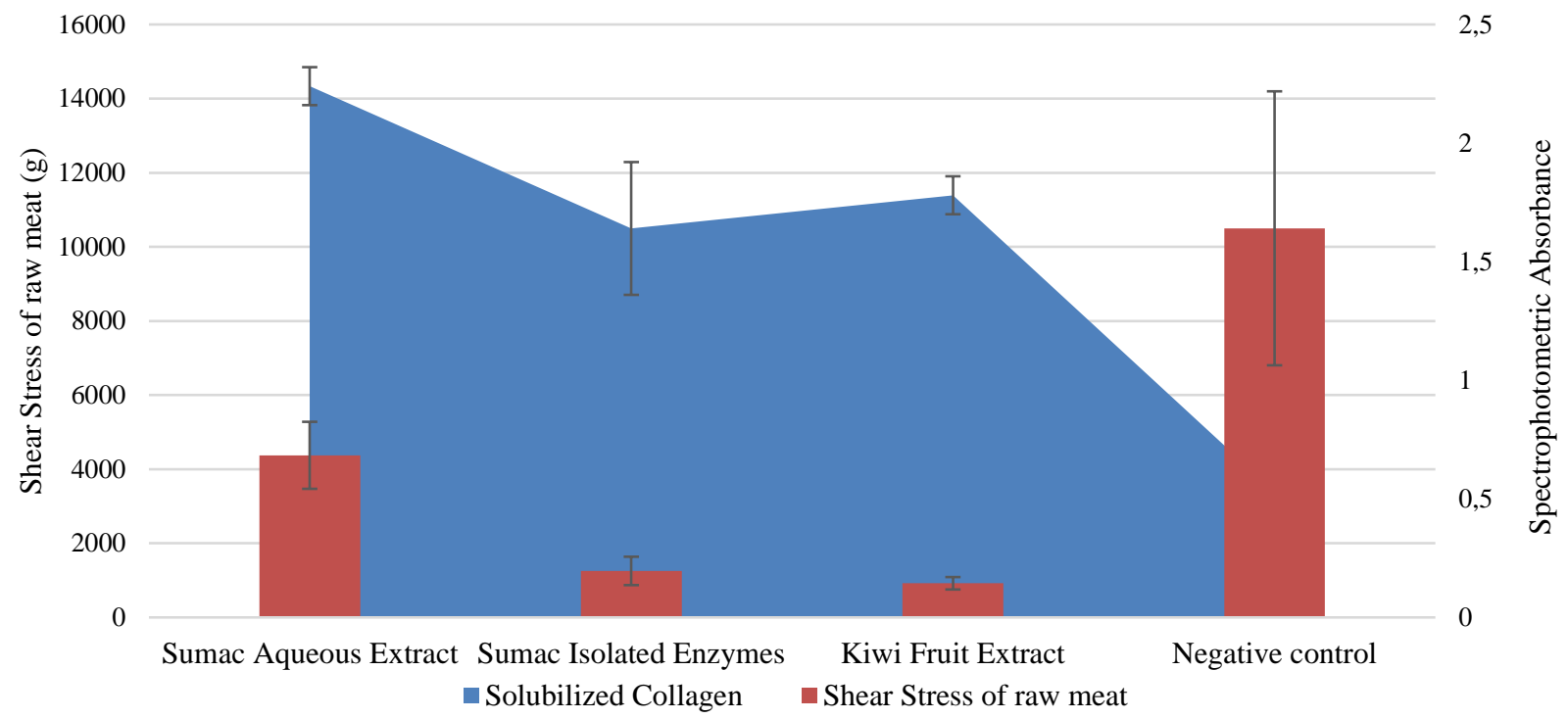

Figure 10 Graph showing the correlation between the amount of collagen extracted and the shear stress on raw meat with each treatment

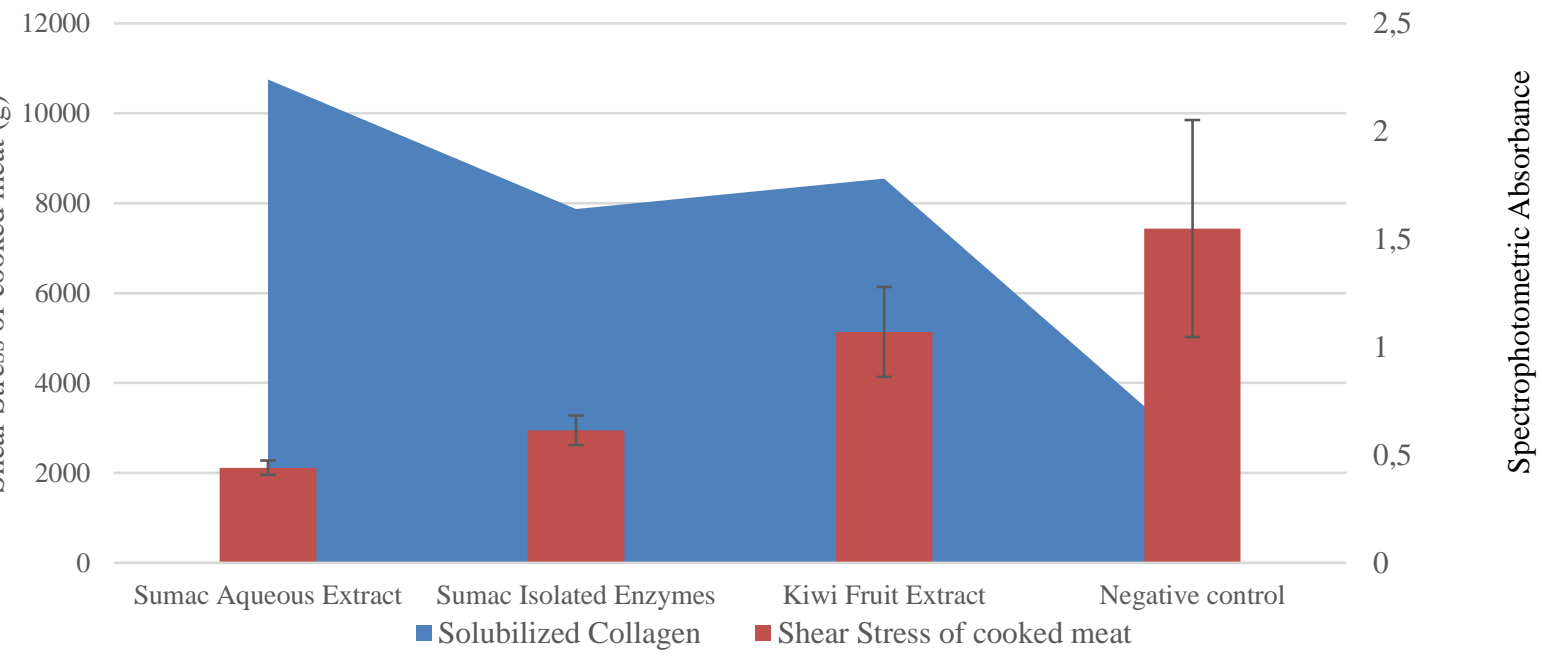

Figure 11 Graph showing the correlation between the amount of collagen extracted and the shear stress on cooked meat with each treatment 
Shear stress versus amount of stromal protein: This comparison was done to evaluate whether the shear stress values were affected by the amount of stromal protein in all treatments. The high heat process to which the meat was subjected solubilizes the collagen into a water solution. After filtration, the solution is composed of only water and collagen.

In the raw meat samples, the results positively confirm that the lower the amount of collagen solubilized by the treatment, the higher the shear stress and thus, the tougher the meat (Figure 10). As shown in figure 10, the collagen extracted from the negative control untreated meat was the lowest among all treatments (0.16) and showed the highest shear stress value $(10.5 \mathrm{~kg})$. Alternatively, SAE, SIE and KFE had a higher amount of extracted collagen (1.28, 0.49, and 0.59 respectively) after treatment and showed much lower shear stress values $(4.3 \mathrm{~kg}, 1.2 \mathrm{~kg}$ and $0.92 \mathrm{~kg}$ respectively) compared to the negative control. SAE had eight times more collagenase activity than the negative control and showed 59\% lower shear stress values. Similarly, in SIE and KFE, the more the collagen extracted, the lower the shear stress.

On the other hand, in the cooked meat samples, although the results were similar to the raw meat samples and still lower than that of the negative control, the shear stress of the KFE and SIE treated meats showed higher values (Figure 11). Alternatively, the SAE treated meat showed a lower shear stress value. This may be explained by the effect of cooking of the muscle fibers and fat (King, 2006). In the SAE treated meat, because its effect on collagen was very high, the collagen solubilized even further after cooking, giving a tenderer meat cut.

\section{Study Limitations}

- The meat used could not be retrieved from a single animal source, although bought from the same butcher every time.

- The meat cuts' shear stress was not measured immediately after cooking because of the unavailability of the texture machine in the lab. The meat was cooked in the lab and directly taken to the Poppins Company in order to be measured using the Texture Analyzer machine.

- Most research papers on meat tenderness follow the Warner-Bratzler procedure of meat tenderness evaluation. We were unable to use it specifically due to the unavailability of the machine, but we could apply a similar procedure using a texture analyzer.

- Studies on meat collagen quantitation and characterization using spectroscopy are lacking and sometimes contradictory.

- The meat used in our study is different from the one analyzed by the Bovine Myology Institute to which we referred. Therefore, the results could not be precisely comparable.

\section{Conclusion and Future Studies}

Sumac fruit has the potential to be used as a meat tenderizer. Our results confirmed that Sumac Aqueous Extract and the Sumac Isolated Enzyme extract both had a direct effect on the meat muscle and collagen, which supports our second objective. As a plus, the hydrolytic effect of Sumac Fruit Extract on collagen is higher than that of kiwi fruit. Moreover, a clear effect on fat was seen, decreasing the fat content of the meat in vitro, thus confirming our third hypothesis which stated that sumac extracts have a hydrolytic effect on meat fat content. The effect of sumac fruit on fat should be further evaluated and its possible use in vivo as a cholesterol decreasing agent and "fat burner". Also, the effect of sumac fruit on fat may not be correlated with $\mathrm{pH}$ but an acidic medium may be more suitable for the enzymes present in sumac to function efficiently. To confirm this hypothesis, the optimal temperature and concentration for the efficiency of Sumac fruit enzyme should be analyzed as well as an ideal $\mathrm{pH}$ for its action. Shear stress is directly correlated to amount of collagen in meat, and thus, affected by the solubility of collagen upon treatment. The higher the effect of the treatment on collagen, the lower the shear stress. More indepth collagen solubility studies should be made using sumac fruit extracts. Complementary studies should be done on the tenderizing effect of Sumac Fruit Extracts on meat. Also, the effect of time on the physiochemical properties of Sumac should be further investigated.

\section{References}

Abdelmalek A. 2013. The Effect of Different Spices on increasing Poultry Meat Shelf Life. Assiut Environmental Research Journal. Volume 38.

Abed OO, Arkan MA, Kholoud AJ. 2013. The Antibacterial Effect of Sumac and Myrtle Extracts on the Bacteria Causative of Soft Rot Disease in Potatoes. Babilonia University Journal. Volume 21.

AbouReidah I, Jamous R, Shtayeh M. 2014. Phytochemistry, pharmacological properties and industrial applications of Rhus coriaria L. JJBS. Volume 7. Pages 233-244. Palestine.

AlJaber G. 2008. Antibacterial effect of two phenolic extracts from Rhus coriaria. BRJ. Volume 22: 22-32. Iraq.

Almouwaly K, Alflayeh K, Ali A. 2013. Antioxidant and free radical scavenging effects of Iraqi sumac Rhus coriaria $\mathrm{L}$. BSJ. Volume 10: 921-933. Iraq.

Anaee R, Abdullah H, Tareq M. 2016. Sumac extract as green inhibitor for steel in seawater. IJSRSET. Volume 2: 353-358. Iraq.

Anweri T, Sharma M, Khan G, Iqbal M, Ali M, Alam M, Safhi M, Gupta M. 2013. Rhus coriaria ameliorates insulin resistance in non-insulin-dependent diabetes mellitus (NIDDM) rats. APPDR. Volume 70: 861-867. Saudi Arabia.

Araújo I, Bezerra T, Nascimento E, Gadelha C, Santi-Gadelha T, Madruga M. 2018. Optimal conditions for obtaining collagen from chicken feet and its characterization. JFST. ISSN 1678457X. DOI: https://doi.org/10.1590/fst.27517. Brazil.

Ardalani H, Moghadam M, Hadipanah A, Fotovat F, Azizi A, Soltani J. 2016. Identification and characterization of chemical composition of Rhus coriaria L. fruit from Hamadan, Western Iran. Journal of Herbal Drug. Vol. 6, No. 4: 195-198. Iran.

Arshad M, Kwon J, Imran M, Sohaib M, Aslam A, Nawaz I, Amjad Z, Khan U, Javed M. 2016. Plant and bacterial proteases: A key towards improving meat tenderization, a mini review. Cogent Food and Agriculture. Volume 2: 1261780. DOI: http://dx.doi.org/10.1080/23311932.2016.1261780. Pakistan.

Arunmozhivarman K, Abraham R, Rao A, Parthiban M. 2017. Extraction and Molecular Characterization of Collagen from Poultry meat Processing by-Product (Chicken Skin). Int. J. Pure App. Biosci. Volume 5 (5): 1085-1091. DOI: http://dx.doi.org/10.18782/2320-7051.5337 
Asgarpanah J, Saati S. 2013. An overview on phytochemical and pharmacological properties of Rhus coriaria L. RJP. Volume 1: 47-54. Iran.

Bekhit A, Hopkins D, Geesink G, Franks P. 2014. Exogenous proteases for meat tenderization. CRFSN. Volume 54: Pages 10121031. DOI: https://doi.org/10.1080/10408398.2011.623247

Bellew J, Brooks J, McKenna D, Savell J. 2002. Warner-Bratzler shear evaluations of 40 bovine muscles. MSJ. Volume 64: 507-512. DOI: 10.1016/S0309-1740(02)00242-5. USA.

Bergman I. and Loxley R. 1963. Two improved and simplified methods for the spectrophotometric determination of hydroxyproline. JAC. Volume 35:1961.

Bursal E, Köksal E. 2011. Evaluation of reducing power and radical scavenging activities of water and ethanol extracts from sumac Rhus coriaria. FRI. Volume 44: 2217-2221. DOI: 10.1016/j.foodres.2010.11.001. Turkey.

Calkins C, Sullivan G. 2007. Adding Enzymes to Improve Meat Tenderness. R\&KM National Cattlemen's Beef Association. www.beefresearch.org.

Chaiwut P, Pintathoga P, Rawdkuen S. 2010. Extraction and three-phase partitioning behavior of proteases from papaya peels. JoPB. Volume 45: 1172-1175. Thailand.

Christensen M, Torngren M, Gunvig A, Rozlosnik N, Lametsch R, Karlsson A, Ertbjerg P. 2009. Injection of marinade with actinidin increases tenderness of porcine $M$. biceps femoris and affects myofibrils and connective tissue. JoSFA. Abstract.

Codex Alimentarius. 1999. Recommended Methods of Analysis and Sampling CXS 234-1999. International Food Standards.

Cross HR, Carpenter ZL, Smith GC. 1973. Effects of intramuscular collagen and elastin on bovine muscle, tenderness. Journal of Food Science. Volume 38: 998.

Dabas D. 2016. Polyphenols as Colorants. Adv Food Technol Nutr Sci Open J. Volume 2: S1-S6. DOI: 10.17140/ AFTNSOJ-SE-2-101USA.

Dinh T. 2006. Meat quality: understanding of meat tenderness and influence of fat content on meat flavor. Science \& Technology Development. Volume 9: 65-70.

Dogan A. 2015. Potential therapeutic properties of Rhus coriaria on streptozotocin-induced diabetic rats. Yuzuncu YIL University. Volume 54: 2092-2102. DOI: https://doi.org/10.3109/13880209.2016.1145702. Turkey.

Duman Y, Kaya E. 2013. Three-Phase Partitioning as a Rapid and Easy Method for the Purification and Recovery of Catalase from Sweet Potato Tubers (Solanum tuberosum). Appl Biochem Biotechnol. Volume 170: 1119-1126. DOI 10.1007/s12010-013-0260-9

Ertürk O. 2010. Antibacterial and Antifungal Effects of Alcoholic Extracts of 41 Medicinal Plants growing in Turkey. Czech J. Food Sci. Vol. 28 No. 1: 53-60. Turkey.

Font-i-Furnols M, Candek-Potokar M, Maltin C, Povse M. 2015. A handbook of reference methods for meat quality assessment. European Cooperation in Science and Technology.

Food and Agriculture Organization of the United Nations, FAO. 1986. Manuals of Food Quality Control; Food Analysis: General Techniques, Additives, Contaminants and Composition. FAO Food and Nutrition Paper. Rome.

Gagaoua M, Hafid K, Hoggas N. 2016. Data in support of three phase partitioning of zingibain, a milk-clotting enzyme from Zingiber officinale Roscoe rhizomes. Elsevier Data in Brief. Volume 6: 634-639. DOI: https://doi.org/10.1016 /j.dib.2016.01.014. Algeria.

Gagaoua M, Hoggas N, Hafid K. 2014. Three phase partitioning of zingibain, a milk-clotting enzyme from Zingiber officinale Roscoe rhizomes. Int. J. Biol. Macromol. Volume 73: 245 252. DOI: http://dx.doi.org/10.1016/j.ijbiomac.2014.10.069 014. Algeria.
Handa S, Khanuja S, Longo G, Rakesh D. 2008. Extraction Technologies for Medicinal and Aromatic Plants. International Centre for Science and High Technology. Italy, Earth, Environmental and Marine Sciences and Technologies. Hanna Instruments. $\mathrm{pH}$ measurement SOP.

Hill F. 1966. The solubility of intramuscular collagen in meat animals of various ages. Journal of Food Science. Volume $31: 161$.

Hosseinzadeh J, Feyzollahzadeh M, Afkari A. 2013. The physical and chemical properties of kiwifruit harvested at four stages. Bulg. J. of Agri. Sci. Volume 19: 174-180. Iran.

Institute of Agriculture and Natural Resources. Bovine Myology. 2017. University of Nebraska. USA. (https://bovine.unl.edu/main /index.php?lang=English \&musID=86\&muscle=null \&what $=$ muscleDescriptions\&listBy=commonName)

Jin Y, Fu W, Ma M. 2011. Preparation and structure characterization of soluble bone collagen peptide chelating calcium. African Journal of Biotechnology. Volume 10: 10204-10211. DOI: 10.5897/AJB10.1923. China.

King N, Whyte R. 2006. Does it look cooked? A Review of Factors that Influence Cooked Meat Color. JoFS. Volume 71: R31-R40. DOI: 10.1111/j.1750-3841.2006.00029.

Kossah R, Nsabimana C, Zhang H, Chen W. 2010. Optimization of extraction of polyphenols from Syrian Sumac (Rhus coriaria) and Chinese Sumac (Rhus typhina) Fruits. RJoPhytochem. Volume 4: 146-153.

Kossah R, Nsabimana C, Zhao J, Chen H, Tian F, Zhang H, Chen W. 2009. Comparative Study on the Chemical Composition of Syrian Sumac (Rhus coriaria L.) and Chinese Sumac (Rhus typhina L.) Fruits. Pak. J. Nutr. Volume 8: 1570-1574.

Lewis D. 1988. Application of actinidin from kiwifruit to meat tenderization and characterization of beef muscle protein hydrolysis. Journal of Food Biochemistry. Volume 12: 147158. DOI: $10.1111 / j .1745-4514.1988 . t b 00368 . x$ USA.

Listrat A, Lebret B, Louveau I, Astruc T, Bonnet M, Lefaucheur L, Picard B, Bugeon J. 2016. How Muscle Structure and Composition Influence Meat and Flesh Quality. The Scientific World Journal.

Lovrien R, Dennison C. 1997. Three Phase Partitioning: Concentration and Purification of Proteins. Book: Protein Expression and Purification. Volume 11: 149-165. New York.

Lucas J, Castaneda D, Hormigo D. 2017. New trends for a classical enzyme: Papain, a biotechnological success story in the food industry. Trends in Food Science and Technology Elsevier. DOI: 10.1016/j.tifs.2017.08.017. Spain.

Meat Technology Information Sheet. 1998. Crude Fat Determination - Soxhlet Method. Food and Science Australia.

Mitchell H, Zimmerman R, Hamilton T. 1926. The Determination of the Amount of Connective Tissue in Meat. Department of Animal Husbandry, University of Illinois. http://www.jbc.org/

Mohammadi S, Kouhsari M, Feshani M. 2010. Antidiabetic properties of the ethanolic extract of Rhus coriaria fruits in rats. DARU J. of Pharm. Sci. Volume 18: 270-275. Iran.

Morgan J, Savell B, Hale D, Miller R, Shackelford S. 1991. Traits of "Tender" and "Tough" meat. J. Anim. Sci. Volume 69: 3274-3283.

Nagappan R. 2012. Evaluation of aqueous and ethanol extract of bioactive medicinal plant, Cassia didymobotrya (Fresenius) Irwin \& Barneby against immature stages of filarial vector, Culex quinquefasciatus Say (Diptera: Culicidae). Asian Pacific Journal of Tropical Biomedicine. Volume 9: 707-711. DOI: 10.1016/S2221-1691(12)60214-7. Ethiopia.

Narsaiah K, Shyam N, Suresh K, Borah D, Desh B, Singh S. 2010. Tenderizing effect of blade tenderizer and pomegranate fruit products in goat meat. J Food Sci Technol Volume 48: 61-68. DOI 10.1007/s13197-010-0127-9. Italy. 
Ozcan M, Haciseferogullari H. 2004. A condiment sumac fruits: some physicochemical properties. Bulg. J. of Plant Physiol. Volume 30: 74-84. Turkey.

Rachana C, Jose V. 2014. Three Phase Partitioning - A Novel Protein Purification Method. National Institute of Animal Nutrition and Physiology. Volume 6: 3467-3472. India.

Raodah M, Alia Z, Feleeha H. 2014. The antioxidant and Antimicrobial activity of Syrian Sumac (Rhus coriaria) Fruits Extract. J. of Nat. Sci. R. Volume 4: 36-40. Iraq.

Recommendations of the Nomenclature Committee of the International Union of Biochemistry and Molecular Biology on the Nomenclature and Classification of Enzymes by the Reactions they Catalyze. http://www.sbcs.qmul.ac.uk /iubmb/enzyme/

Runs K, Wui D, Pritchard R. Steps for Warner-Bratzler Shear Force Assessment of Cooked Beef Longissimus Steaks at South Dakota State University. Department of Animal and Range Sciences. USA.

Schmid F. 2001. Biological Macromolecules: UV-Visible Spectrophotometry. Encyclopedia of Life Sciences. DOI: https://doi.org/10.1038/npg.els.0003142

Seggern V, Drew D, Calkins, Chris R. 2005. Physical and Chemical Properties of 39 Muscles from the Beef Chuck and Round. Nebraska Beef Cattle Reports. 323. http://digitalcommons.unl.edu/animalscinbcr/323

Sepos E. 2012. Standard Operating Procedure Rotary Evaporator in the P.O.W.E.R. Laboratory.

Shabbir A. 2012. Rhus coriaria Linn, a Plant of Medicinal, Nutritional and Industrial Importance: A Review. Journal of Animal and Plant Sciences. Volume 22: 505-512. Pakistan.

Shackelford S, Wheeler T, Koohmaraie M. 1999. Evaluation of Slice Shear Force as an Objective Method of Assessing Beef Longissimus Tenderness. American Society of Animal. Volume 10: 2693-2699. DOI: 10.2527/1999.77102693x
Sharmila S, Rebecca J, Das M, Saduzzaman M. 2012. Isolation and partial purification of Protease from plant leaves. Journal of Chemical and Pharmaceutical Research. Volume 6: 11531156. India.

Shidfar F, Hosseinic S. 2014. The Effect of Sumac Rhuscoriaria L. Powder on Serum Glycemic Status, ApoB, ApoA-I and Total Antioxidant Capacity in Type 2 Diabetic Patients. Iranian Journal of Pharmaceutical Research. Volume 13: 1249-1255.

Sugiyama S, Hirota A, Okada C, Yorita T, Sato K, Ohtsuki K. 2005. Effect of Kiwifruit Juice on Beef Collagen. J Nutr Sci Vitaminol. Volume 51: 27-33. Tokyo, Japan.

VELP Scientifica. Nitrogen and Protein Determination in Meat according to the Kjeldahl method. Reference: AOAC 981.10 Crude Protein in Meat.

Wada M, Suzuki T, Yaguti Y, Hasegawa T. 2002. Effects of pressure treatments with kiwi fruit protease on adult cattle semitendinosus muscle. Journal of Food Chemistry. Volume 78: 167-171.

Wall K, Kerth C, Miller R, Alvarado C. 2017. Grilling temperature effects on tenderness, juiciness, flavor and volatile aroma compounds of aged ribeye, strip loin, and top sirloin steaks. MSc Thesis. Texas A\&M University.

Whitehurst R, Oort M. 2010. Enzymes in Food Technology. $2^{\text {nd }}$ Edition. Chapter 12.

Wilson M, Felker J. 2011. Better Crops with Plant Food. International Plant Nutrition Institute. Vol. 95. Page 27. Canada.

Yu T, Morton J, Clerens S, Dyer J. 2016. Cooking-Induced Protein Modifications in Meat. Comprehensive Reviews in Food Science and Food Safety. Volume 16: 141-159. DOI: $10.1111 / 1541-4337.12243$

Zhu X. 2017. Actinidin Treatment and Sous Vide Cooking: Effects on Tenderness and In Vitro Protein Digestibility of Beef Brisket. MSc Master Thesis. Massey University. New Zealand. 